\title{
Tramway as an indicator of the realisation of Smart City concept
}

\author{
Ivan Savchuk ${ }^{1 *}$, and Tymofii Nahornyi ${ }^{2}$ \\ 'Institute of Geography, National Academy of Sciences of Geography, Kyiv, Ukraine \\ ${ }^{2}$ Taras Shevchenko National University of Kyiv, Ukraine
}

\begin{abstract}
Nowadays, the world's leading cities are focused on the Smart City concept, due to the widespreading of innovations that enhance quality of life. The need for sustainable development for the harmonious prolongation of the humanity existence raises attention to attempts for improving the economic, social and environmental conditions. Among the modes of transport, the most harmonious in the modern city, which strives for sustainable development, is the tramway. The experience of the tramway renaissance during the last decades indicates that it is not only a mode of transport but also a positive impact on the urban space and community. In the context of Ukraine's integration into the European Community, it is important to analyse the experience of cities that have been successful in implementing urban transport innovations. In the article, we compare the cities of Kyiv and Budapest to find spatial patterns that should be obeyed for the sustainable development of a post-socialist city based on smart solutions.
\end{abstract}

\section{Introduction}

The concept of Smart City involves the use of contemporary technologies to improve the quality of life. However, innovation alone cannot meet this challenge. In order to achieve sustainable economic, social and environmental development, it is necessary to combine the latest theoretical developments with practical urban planning experience over the last decades. This makes it possible to test in practice the example of specific cities for the feasibility of applying sustainable development conditions [13].

Mobility is one of the top priorities in the city's development. On the one hand, IT technologies are intended to provide the city authorities with the necessary information in the form of Big Data for the development of theoretical models, on the basis of which it is possible to solve specific issues of improving the transport situation in the city [11]. On the other hand, it is important to provide real-time information to transport users for optimum travel planning. At the same time, the emphasis is on providing intermodal connections. In order to do this, the city must ensure close links between public and private transport and develop micro-mobility, including pedestrian and bicycle traffic. In the last decade only, the latter have become important component of master plans for post-socialist cities.

Post-socialist cities are now in a situation where the dilemma of public and private transport arises. In the 60-80's of the 20th century, the countries of the world divided between the capitalist and socialist regimes began to differentiate clearly in terms of mobility patterns.

\footnotetext{
${ }^{*}$ Corresponding author: timich123456@gmail.com
} 
The Global West went the way of mass motorization, which led to the degradation of public transport systems and urban space. The Global East had a relatively low level of motorization at that time (up to 100-150 cars per 1,000 inhabitants) [6]. Instead, public transport was rapidly developing to, first and foremost, meet the demand for work trips between large housing estates and industrial sites. Following the collapse of socialism in Eastern Europe and Central Asia, the breakdown of mobility patterns accelerated, with the refusal of state subsidies for public transport and the start of mass motorization. Unlike other economic processes and phenomena, in the transport sector, demand does not create a supply. British mathematician Martin Mogridge says: "The more roads are constructed, the more traffic appear to fill them" [10].

Post-socialist cities have reproduced the processes associated with the mass motorization that the Global West experienced in 60-90's. In response to the negative effects of this way of development, the countries split into two opposite directions, in which they planned to further regulate the sphere of mobility. Central and Eastern Europe, as well as some Balkan countries, have adopted appropriate standards and launched programs to moderate motor vehicle usage and to encourage intensive development of public transport and provide quality and safe pedestrian and bicycle infrastructure, due to their progress of integration into the European Community [7]. Their strong point was that they were left with extensive public transport systems inherited from the socialist past, in particular the tramway, which needed no more than just quality development. Instead, the post-Soviet countries continued to move by inertia, prioritizing operational mobility solutions rather than strategic ones. The issue of mass car use was tried to solve by the construction of new roads and multi-level interchanges. Public transport have experienced lack support from cities' authorities. The result is degradation or complete closure, in particular of tramway and trolleybus systems. For example, seven tramway systems were closed in Ukraine in 1991-2020, and a complete shutdown of the trolleybus system in Moscow is planned for September 2020 - the largest trolleybus system in the world just five years before.

Instead, in the leading smart cities of the world, even before the digital revolution, the process of qualitative development of public transport and its integration into urban space began. This process is known as the tramway renaissance. Emphasis was focused on this mode of transport, giving the high capacity of modern streetcars, their constant dimensions (which is the key to compact placement on city streets) and people's subconscious commitment to the tram as one of the symbols of the city and urban lifestyle. In the context of Ukraine's integration into the European Community, it is important to learn from the experience of cities that have succeeded in implementing innovations in transport to harmonize local business, community and social justice development, as well as the environmental situation. Therefore, we take a closer look at the examples of the cities of Kyiv (Ukraine) and Budapest (Hungary) in order to find out the spatial patterns that should be obeyed for the sustainable development of the city using smart solutions.

\section{Results and Discussion}

The main hypothesis of our research is the following: the tram is a prerequisite for the implementation of the Smart City concept, as well as it is a consequence of its successful implementation. 
The tramway is the first mass transit mode. The first horsecar tramway system opened in Swansea (Wales) in 1807. With the introduction of innovative electric engine in Berlin (Germany) in 1880, tram transport was widely used in cities in Europe and North America. Basically, it became the subject of business on the basis of municipal-private partnership. This mode of transport has been particularly developed in cities with hilly terrain - the socalled cablecars [1].

The proliferation of mass motorization and housing suburbanization policies have over time displaced trams from the urban streets of America and Canada, and after World War II - Western Europe [21]. Subsequently, this resulted in a negative synergy. Cities have grown extensively, so land use has become extremely inefficient for the urban economy, and commuting has been getting longer. Road construction did not keep up with demand for mass road trips, causing new congestion. Different districts became monofunctional (such as suburban "dormitories" and central business districts), and homogeneous areas appeared where racial or property segregation was pervasive. Degradation of the central business districts of cities has occurred due to their mono-functionality ("extinction" during nonworking hours) and the use of significant land resources for parking purposes. This was particularly threatening to Europe, given its considerable historical and cultural framework, especially in the downtowns. Formed in the second half of the twentieth century. the urban intellectuals began to demand and promote a social inquiry for a qualitatively new urban planning that would focus not on cars but people [18].

Therefore, some cities in Europe, Canada, and the United States have established new tramway systems that are similar to the metro (subway) in terms of efficiency, but have used predominantly land-based tracks and lighter rolling stock. The classic tramway has evolved into light rail transit (LRT). Thus, the process of renewal and activation of the construction of new tramway lines and systems arose around the world (Figure 1).

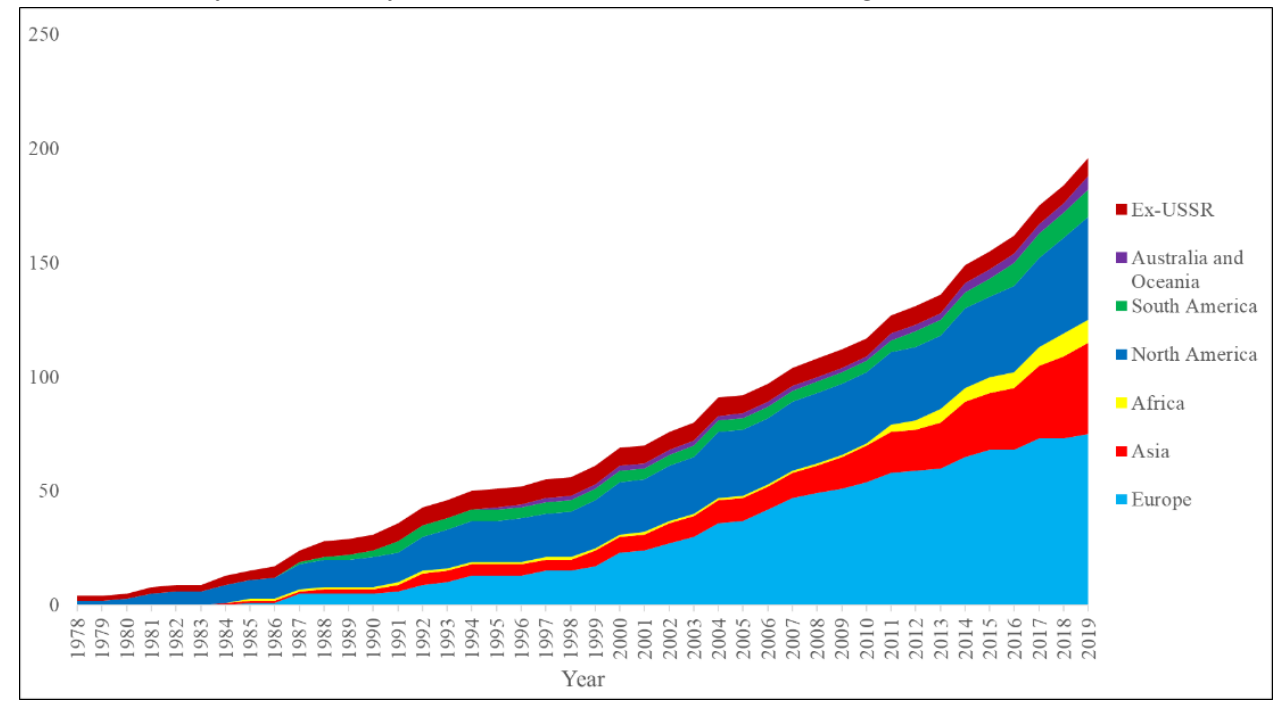

Fig. 1. Tramway rennaissance - number of newly established tramway systems by world regions in 1978 to 2019 
The situation in the socialist countries was quite different. First, the land was state-owned, so it cost nothing in the open market and construction was regulated only by the Party's official policy. Secondly, there was no mass distribution of cars. The Skoda plants in the Czech Republic or Ikarus in Hungary dealt primarily with the production of buses and trolleybuses for public transport needs, as well as services transport, including the military needs. Thus, socialist cities had better preserved base for quality public transport development at the end of the 20th century. Thus, the tramway became one of the factors behind the new development of the post-socialist city [8].

\subsection{Technology for Ecology}

The tramway is the most environmentally friendly mode of public transport, both due to the rolling stock used and the environment that such a system forms around.

The only direct waste of tram work is metal shavings, which are formed through friction of wheels and rails. At the same time, the trolleybus has exhaust rubber tire emissions that adversely affect soil and atmospheric air. Modern tram cars mostly have the asynchronous motor that allows braking with recovering some of the electricity back into the grid. In addition, trams use less electricity during operation than trolleybuses or electric buses due to less adhesion of metal wheels to the rail surface than rubber to asphalt. In doing so, safety is offset by a more advanced braking system for trams that have four independent brakes as opposed to three on the trolleybus and two on the bus [1].

Due to the constant trajectory of tracks and the lowest possible transport emissions, the trend in Europe and North America is observed to increase the environmental attractiveness of tramway lines by planting grass or lawn on the soil between the rails. The albedo indicator of asphalt is $11-15 \%$, open soil $16-20 \%$, while grass cover $21-25 \%$ respectively so it repels the solar heat most effectively. This use of the vacant space between the rails reduces the urban heat island effect. In addition, the repelling of more solar heat avoids overheating of tramway rails and such phenomena as "rail ejection" [14].

The disadvantage of the tramway system is the low flexibility of its network. However, as in the case of the metro, this is offset by the dense housing and all kinds of infrastructure that attracts customers traveling on public transport. The concept of transit-oriented development offers ways and measures for the organic combination of the trunk public transport lines with residential buildings and community centers. Unlike the car-oriented development concept which characterized the suburban housing development and territorial sprawl of services. Cities endeavouring livability, locate periodic and episodic consumption infrastructure and services near metro, commuter rail stations or tramway stops. Thus, the rail frame of the city provides a higher availability and alternative to private cars, which are one of the main contributors in air pollution. The city that develops this way is more compact, and therefore the rates of extensive use of green areas or farmland are much smaller [20].

\subsection{Democracy and Transport}

The first mode of public transport in history was called the omnibus ("for everyone" in Latin). Contemporary public transport, unlike the motorized traffic, is accessible to people, regardless of age, gender, financial situation, physical or mental disabilities. This defines its theoretically high inclusivity, which, however, has some variation among its modes.

All metro systems that have been established in socialist countries have deep occurrence stations which considered to be underground shelters during the Cold War. With the absence 
of elevators at such stations (except escalators), they are literally inaccessible to people with disabilities or ones with baby carriages.

With low-floor rolling stock and platform arrangements at tramway stops, it is the most inclusive mode of mass transit thanks to its constant trajectory.

In the perspective of development of new areas of the city based on the concept of transitoriented development (including on the basis of the tramway network), an important issue is the formation of a dense medium-sized buildings (up to 5 to 7 floors), which would have a variety of functional purpose and owners. It is worthwhile to combine the lease of commercial space with both network market players and local small and medium businesses. Part of the new housing should be social housing for groups such as young families, people with disabilities, students and else. This aims to create a heterogeneous environment that will not tend to "extinction" at different times of the day. The environment of such a "low city" leads to the formation of social control of the situation on the streets, incl. criminal. An important aspect is the visual contact with public transport infrastructure. Streets with tramway rails are more attractive to investors and tenants, given the sense of permanent accessibility of customers. Such areas show high economic and social efficiency and also create a safe environment for all population groups [19].

\subsection{Economy and Saving}

The tramway is the most energy efficient mode of public transport. In addition to the mentioned aspect of electric recuperation, the tram consumes less energy than a trolleybus (thanks to easier sliding of wheels on rails) and less than metro (due to the lack of the need to keep passenger and technical facilities at stations). Thus, in 1961-1990, a tram ticket in Kyivused to cost the least of all modes of transport (3 kopiikas against 4 kopiikas for trolleybus or 5 kopiikas for bus or metro). Some tram systems show exceptional efficiency in passenger traffic as an alternative to the metro [5]. In this context, an important issue is the efficiency of taxpayers' spending on trunk public transport development projects. According to railwaygazette.com, metro lines opened in 2019-20 had construction costs ranging from 29 million USD per kilometer (Barcelona, Spain) to 110 million USD per kilometer (Hohhot, China). Some projects cost more than 500 million USD per kilometer (London, the UK). The kilometer of the new tramway lines ranged from 5 million USD (Daugavpils, Latvia) to 40 million USD (Utrecht, the Netherlands). 


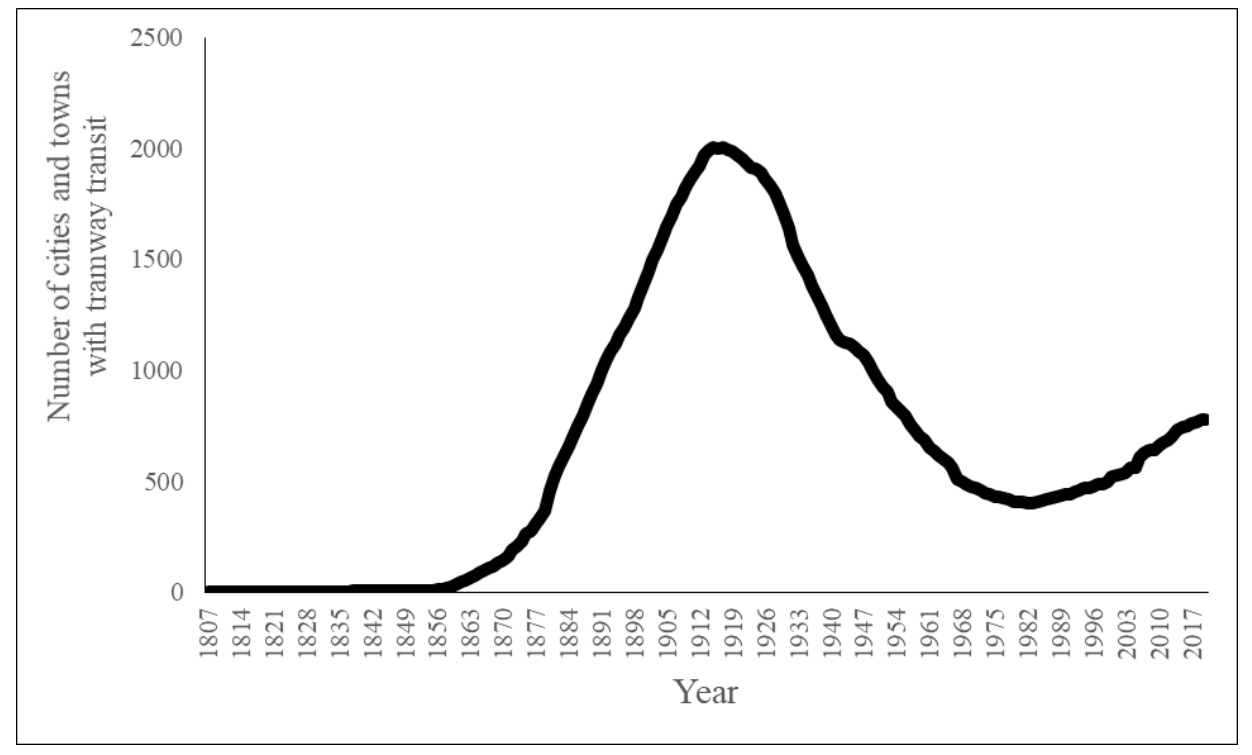

Fig. 2. Number of cities and towns with tramway transit around the world (1807 to 2019)

Municipal-private partnership schemes are used for optimal planning of the construction and modernization of the tramway network in different cities [4]. In this context, the city authorities should carry out a wide-ranging information campaign to clarify the positive effects of transit-oriented development and to prevent outdated stereotypes among residents and businesses. The attractiveness of public transport hubs with tramway stops for the location of commercial infrastructure is clearly traced [12]. For example, the construction of a shopping mall at "Kiltseva Doroha" LRT station is being completed in Kyiv in February 2020, and a new line to the Savoya Park Shopping Center was opened in Budapest in 2014.

\subsection{Analysis of Kyiv and Budapest plans for innovation in mobility}

Kyiv and Budapest have similar conditions for development as a post-socialist city. Since the collapse of the socialist bloc, there have been significant changes in the economic system, social structure and patterns of the urban environment. The opaque real estate market has led to a chaotic housing development of some parts of the city districts with a load on stagnant infrastructure [8]. The influence of central government, located in the capitals, formed some aspects of urban infrastructure development, such as the laying of a metro line between the government quarter and the train stations in the 60-70's. The establishment of the free vehicle market resulted in a surge in mass motorization, which, according to 2014 data, amounts to 350 cars per 1,000 inhabitants in Budapest [2] as well as 213 and 257 per 1,000 residents in Kyiv into 2015 and 2017 respectively [17] . At the same time, the rate of motorization in the capital of Ukraine is increasing due to the trend towards the import of cheap diesel cars from Poland and Lithuania.

The planning structure of both cities is formed in such a way that in the downtowns, formed by the quarter development, the radial-ring structure of streets passes through the 
outskirts of the city into the suburbs of the city into rectangular or arbitrary structures. The density of the road network decreases in the direction from the center to the periphery of the city.

The natural conditions of the two cities resemble a mirror. Kyiv is located on both banks of the Dnieper river, with the central part of the city located on the right, hilly bank. Budapest was formed in the nineteenth century by three cities (Pest, Buda and Obuda) on both banks of the Danube. Its business, cultural and tourist center, in turn, is on the left bank of the lowland Pest, and the Buda combines residential areas (lakótelep), university campuses, and recreational areas in the Buda Hills.

Budapest's development is guided by the principles of integrated development, so all strategic planning documents form a single system and are not contradictory. The main one is Budapest 2030 Long-Term Urban Development Concept. It integrates professional research of the current state of the city, identifies major development goals based on the principles of quality of life, sustainability and equal opportunity, and, finally, offers directions for the implementation of these principles and goals. Below the hierarchy there are the programs that are most relevant to the topic of our research - The Smart City Vision of Budapest and the Budapest Transport Development Strategy (Balázs Mór Plan). It is important that all urban planning documents of Budapest are developed in parallel, the latest revisions were approved and published in 2013-2014 and are oriented towards the strategic goals until 2030.

The Smart City Vision of Budapest [15] rely on the Transport Development Strategy and sets out the basic requirements for the innovative development of a city's mobility system. In particular, the following areas are highlighted:

- Pedestrian friendly Budapest

- Accessible city for cyclists

- Attractive public transport

- Environmentally responsible motorized transport

- Intelligent mobility

- Improving road safety and traffic calming

- Efficient urban logistics

Particular attention is paid to tramway transport. It is noted that the Budapest tramway has the worldwide importance and is therefore an indicator of smart mobility in the city. To enhance its role in the city and improve the service, plans are being announced for rolling stock upgrades, modernisation of existing lines and building new ones, as well as improving passenger awareness and traffic predictability through the introduction of an intelligent traffic management system.

In turn, the Transport Development Strategy [2] declares specific steps to improve the transport system in Budapest. In particular, the city abandones its previous plans to extend the metro line M4 to the northeast of the city to the Újpalota district. Instead, it is proposed to re-develop a tramway line closed in the late 1980s by this direction. Also, in the central part of the city there is a prospect of reviving the tramway on Váci avenue parallel to the M3 metro line, which is currently overcrowded. The radial routes 12 and 14 along this line should be extended to Ferenc Deák Square and combined with routes 47 and 49 . Thus, a new urban rail line may be formed in a north-south direction, which is intended to discharge existing metro lines. The new tramway arteries should be extended to residential areas in the northwest and southeast of the city that do not currently have access to rail public transport.

Urban planning documentation in Kyiv is being developed by various municipal institutions. In addition, there are sectoral projects by international organizations, such as the 
World Bank's Sustainable Urban Transport Plan for Kyiv in 2015 (which Kyiv City Council did not approve as for February 2020). The main urban development document is the Kyiv City Development Strategy for 2025 [16]. Considering the principles of sustainable development, the Strategy proposes optimal, but not timely changes. The General Plan for the Development of the City of Kyiv [3], which exists in three editions in parallel, is based on the principles of Soviet urban planning and offers mass construction of highways, multilevel interchanges and metro lines. It envisages the development of the tramway system exclusively on the outskirts of the city without the prospect of laying new lines in the downtown. This contradicts the development trends of this mode of transport in large cities in highly developed countries. The major project for the development of the tramway in Kyiv, according to the General Plan, would be to extend the Troieshchynska LRT line along the left bank of the city to connect the residential areas of Troieshchyna and Osokorky with them to the metro stations. Therefore, it is proposed to build a light rail transit with a capacity close to the metro for transfering the passengers to overcrowded metro stations and not to the business center of the city, which is not rational.

Since its development in 2012 until 2020, no transport project has been completed under the General Plan for Development of City of Kyiv until 2025. Therefore, while developing a new urban planning document, the real needs and opportunities of the Ukrainian capital for urban transport development should be taken into account. The document does not currently have an integral analysis of the financial capacity of the city. In turn, as of February 2020, work is underway on another document in the field of mobility - the Integrated Transport Scheme.

In 2015, with the support of the World Bank, a Sustainable Urban Transport Plan for Kyiv was prepared [17]. The proposals include the return of the tramway to the city center - the extension of Borshchahivska LRT line from the Central railway station to Palats Sportu metro station. The construction of a modern light rail line in the city center would have a positive impact on the transport situation in the city as a whole, which proves the experience of cities in developed countries of the world. As of February 2020, the Institute of the General Plan of Kyiv strongly opposes this initiative. The World Bank's plan also offers deep infrastructure integration of the tramway and the urban rail in the form of a tram-train system. This involves the integration of the tramway and rail into a single city-wide network with the launch of new generation tram rolling stock. We consider that the tramway connection on the Kyiv railway junction is not appropriate due to the existing intensive passenger and freight traffic of the Ukrzaliznytsia trains on the proposed sections. In addition, international experience with the implementation of tram-train systems, for example, in Paris (France) [14], clearly shows that this is a suburban mode of transport used to concentrate the commuter flow within the urban agglomeration.

\section{Conclusion}

The tramway became the first type of public transport in the world which operates nowadays. $19^{\text {th }}$ century innovation experienced a boom and bust, and then revived in a new form - light rail transit. In modern world, the tramway is an alternative to the metro. The advantages of these modes of transport form the main "rail frame" of the city.

The experience of European cities testifies to the exceptional efficiency of the tramway. Unlike the bus, the tram has not acquired the negative meaning of "transportation for those who cannot afford a car" during the mass motorization era. Streets with appropriate transport services make them more democratic and inclusive. The business tends to concentrate along the tramway corridors due to the accessibility for large numbers of customers. In contrast to 
the centralized location of primarily large businesses and network services around metro stations (due to the polarization of rental rates), tramway corridors are characterized by equal business opportunities at different levels.

The use of eco-innovation is one of the main advantages of tramway transport. Among all modes of urban public transport, it is the most economical in the context of the natural resources usage (both in terms of electricity consumption and intensive land use). The green spaces between the rails and along the tramlines separated from the highways increase the environmental sustainability of the urban space and reduce the urban heat island effect.

Cities seeking to become livable clearly identify the role of the tramway in informal urban planning documents as the basis of a smart city transportation system.

\section{References}

1. A.H. Zilbertal. Problems of urban passenger transport. Moscow-Leningrad, Gosudarstvennoe transportnoe izdatelstvo (1937) [In Russian]

2. Balázs Mór Plan. Budapest Transport Development Strategy 2014-2030. BKK Budapesti Közlekedési Központ Zrt., Badapest, Pannónia-Print (2014)

3. General plan of the development of Kyiv until 2025. URL: http://kga.gov.ua/generalnijplan [In Ukrainian]

4. G.M. Guess. Managing and Financing Urban Public Transport Systems. Open Society Institute, Budapest (2008)

5. I.G. Savchuk, T.V. Nahornyi. Spatial organization of the tramway transport of a big city (on example of Kyiv). Ukr. Geogr. J., 1, 56-62 (2018) [In Ukrainian]

6. J.-P. Rodrigue, C. Comtois, B. Slack. Geography of Transport Systems (Third Edition). New York, Routledge (2013)

7. J. Sadik-Khan, S. Solomonow. Streetfight: Handbook for an Urban Revolution. Penguin Books, New York, New York (2016)

8. K. Stanilov. The Post-Socialist City. Urban Form and Space Transformations in Central and Eastern Europe after Socialism. Springer, Dordrecht, The Netherlands (2007)

9. Mercer Quality of Living Survey 2019. URL: www.mercer.com/qualityofliving

10. M. J.H. Mogridge. Travel in towns: jam yesterday, jam today and jam tomorrow? Macmillan Press, London (1990)

11. M. Madani Larijani, T. Nahornyi, A.M. Crizzle. Using GIS to examine transportation connectivity in Saskatchewan. The Journal of Rural and Community Development, 14(3), 87-99 (2019)

12. O. Dronova, S.D. Brunn. How neoliberal globalization processes are transforming Kyiv's nodal areas. Urbani izziv, Volume 29, No. 2, 96-110 (2018)

13. Planning and design for sustainable urban mobility. Global report on human settlements 2013. NY, UN-Habitat (2013)

14. R. Zelezny. Tramway-oriented development: what results in what context? Comparative approach between France and the Czech Republic. Transportation Research Arena (TRA) 2014, Paris - La Défense, France (2014)

15. Smart Budapest. The Smart City Vision of Budapest. Summary. Budapest 2024 Nonprofit Ltd.

URL: https://budapest.hu/Documents/V\%C3\%A1ros\%C3\%A9p\%C3\%ADt\%C3\%A9si\%20 F\%C5\%910szt\%C3\%A11y/Smart_Budapest_summary_ENG.pdf

16. Strategy of the development of Kyiv until 2025. https://old.kyivcity.gov.ua/files/2017/8/18/Strategie_nouvelle_edition.pdf [In Ukrainian] 
17. Sustainable Urban Transport for Kyiv. World Bank Report. No. 107108 (2016)

18. T. Haas. New Urbanism and Beyond. Designing cities for the future. Rizzoli International Publications, Inc., New York, NY (2008)

19. Transit Street Design Guide. National Association of City Transportation Officials. Island Press, New York City, NY (2016)

20. T. Tuvikene, W. Sgibnev, C.S. Neugebauer. Post-Socialist Urban Infrastructures. London, Routledge, (2019)

21. V.R. Vuchic. Transportation for Livable Cities. CUPR/Transaction (1999) 